\title{
Gender, Religion and Nationalism: Locating Muslim women in Indian Nationalist Discourse in Momtaz Shah Nawaz's The Heart Divided
}

\author{
Suma Chisti \\ PhD Research Scholar, Department of Humanities and Social Sciences, IIT Kharagpur, E- \\ mail: chisti.sumaooo@gmail.com, ORCID: https://orcid.org/oooo-ooo1-7304-7481
}

\begin{abstract}
In the late nineteenth and early twentieth century colonial India, with the dramatic changes in sociopolitical scenario the nationalist discourse in India was significantly reshaped. And with the rise of a new nationalist discourse in India, the position and representation of women in Indian nationalist discourse was rethought and redefined - first, because of the rise of Goddess-centric nationalist rhetoric and secondly, the nationalist leaders' promotion of and call for women participation in the freedom movement. Historian, critics and social scientists find women liberation movement, social reform and cultivation of feminist discourse in India intertwined with the rise of nationalism or national movement in the country. In the late nineteenth and early twentieth century India witnessed the emergence of nationalist concepts of "New Women", "Modern Indian Women" or "Mother India". And the rise of these ideas substantiates both the subjective and objective position of women in Indian nationalist discourse. But so far as the position or representation of Indian Muslim women in Indian nationalist discourse is concerned, it has always been difficult to address the issue. While addressing this problem of the position of Indian Muslim women in Indian nationalist discourse some more points and facts need to be taken into account- first, the rise of Two Nation Theory which demanded a separate country for the Muslims of undivided India; secondly, the emergence of the secularist trend of Indian nationalism; thirdly, the significant rise of Hindu nationalism and fourthly, Muslims' exceptional adherence to the practice of women seclusion due to their religious sentiment. In her novel The Heart Divided (1957) Momtaz Shah Nawaz, a Muslim woman writer of the undivided India, addresses all these concerns. In the novel she tries to figure out a definite role and position of Indian Muslim women in the nationalist discourse of colonial India during anti-colonial movement. My paper tries to explore the position of Muslim women in Indian nationalist discourse through a critical reading of the said novel. It attempts to find out how Muslim women had both the subjective and objective position in Indian nationalism during the freedom struggle. It also tries to address whether the nationalist terms like "New Women", "Mother India" or "Modern Indian Women" are applicable for the Indian Muslim women.
\end{abstract}

Keywords: Nationalism, New Women, Muslim Women, Gender, Religion, Two Nation Theory

\section{Introduction}

In Indian nationalist discourse women have generally been portrayed as the "Mother figure" who would sacrifice her sons or husband for the great national cause. In national struggles in India women have traditionally played, as the masculine discourse has dictated for them, the supporting role of "keeping their homes ready for the warrior-nationalists to return to" (Nayar, 2008, p. 121). In Indian nationalist discourse generally the terms like "honour", "patriotism" and

(C) AesthetixMS 2020. This Open Access article is published under a Creative Commons Attribution Non-Commercial 4.o International License (http://creativecommons.org/licenses/by-nc/4.o/), which permits non-commercial re-use, distribution, and reproduction in any medium, provided the original work is properly cited. For citation use the DOI. For commercial re-use, please contact editor@rupkatha.com. 
"duty" have been thoroughly politicised and masculinised (ibid). But in the late nineteenth and early twentieth century, the political scenario in India changed dramatically and this drastic change in politics significantly reshaped the nationalist discourse in India. And with the rise of this "new" nationalist discourse in India and under the influence of Gandhian nationalism ${ }^{\mathrm{ii}}$, the position and representation of women had to be rethought and redefined. The Britishers' "civilizing mission" for eradicating "anarchy, lawlessness and arbitrary despotism of Indians" against women and for abolishing the "degenerate and barbaric" cultural practices and social customs perpetuated upon women in India contributed significantly to this rethinking of the status and role of women in Indian society (Chatterjee, 1993, p. 117). To establish a counter discourse to the exploitative "civilizing mission" of the colonizers, Indian nationalists decided to launch women liberation movement and to "modernize" the country. However, in this process of "modernizing" the country, women who had conventionally been shut behind the walls of the home space and were supposed to behave like the "perfect" wives and mothers, were allowed to invade the public space. In this juncture the concept of "New Woman" (that we understand as Bhadramahila in the nationalist context in India), or the "Modern Indian Woman" emerged. However, this journey of women from the private sphere of home to the public space debunks the British presentation of Indian woman as a "sign of the inherently oppressive and unfree nature of the entire cultural tradition of a country" (Chatterjee, 1993, p. 622). Moreover, to gain mass support and solidarity against the White masters, the nationalist leaders who had so far been ignoring "the second sex" for its femininity, began to encourage women participation in anti-colonial movement. Thus, women so far subjugated and disregarded, fortunately and suddenly got the ticket for participating in the freedom movement and of finding a political position in the national movement. Thus, the colonisers' call for women emancipation first and the anti-colonisers' promotion of women participation in the freedom movement then gave an identity to women in India. However, notwithstanding this "convenient" situation, only a smaller number of women were seen participating in the nationalist movement and voicing out resistance to British colonial system. And in this context it is needless to say that while configuring the participation of women in Indian nationalist discourse appears to be problematic, finding the Muslim women voices in it would naturally be quite tougher because in the name of preserving modesty, they were often secluded within the Zenana or Burqa. Moreover, while looking into the participation of Muslim women in the nationalist discourse of late colonial India, some more things need to be addressed: firstly, the emergence of the goddess centric nationalist

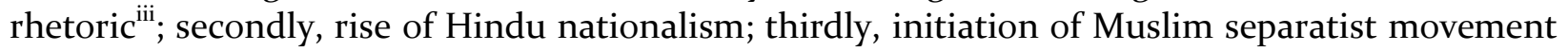
and the demand for Pakistan among the Muslims. In her novel The Heart Divided (1957) Momtaz Shah Nawaz, a Muslim woman writer of the undivided India, addresses all these concerns to figure out a role and position of Muslim women in the nationalist discourse of late colonial India. There are very few Indian Anglophone fictions which have explored the pros and cons of and different responses to the participation of Muslim women in Indian nationalist movement and their position and representation in Indian nationalist discourse ${ }^{\text {iv }}$. In striking contrast to this silence and denial, Muslim female author like Momtaz Shah Nawaz who was a witness to the political happenings and socio-political turmoil during the freedom struggle came forward with her evocative narratives that represent the (his)story of national movement through the eyes of Muslim female protagonists. This paper seeks to explore position of Muslim women in the Indian nationalist discourse through a reading of the aforementioned novel. It also seeks to look into how Muslim women responded to those socio-political turmoil and political happenings which they encountered in their journey from Purdah to politics. It also tries to address whether the nationalist terms like "New Women", "Mother India" or "Modern Indian Women" are applicable for the Indian Muslim women. 
The Heart Divided written in the undivided India in 1947 was posthumously published in 1957 in the independent Pakistan. Set in the 1930s-1940s Lahore of colonial but undivided India, the novel narrativizes the political discourse of late colonial India mainly from the perspectives of the female characters Zohra and her elder sister Sughra. In the novel Zohra has been portrayed as an educated young Muslim woman deeply influenced by the political scenario of 1940s. The novel is the representation of thoughts and experiences of some educated Muslim women of 1930s, the decade when India was getting ready for its independence and consequently the painful partition. It was the time when the contour of the nationalist debate was finally being defined through arguments, debates and negotiations. Shah Nawaz has demonstrated these debates, arguments and negotiations in her novel from the Muslim women perspective. She has vividly captured Muslim women's opinions on the idea of unified India or Jinnah's Two-nation theory. The novel in fact is a picturization of the journey of how Muslim women gained a subjective position in Indian freedom struggle by breaking out of the shackles of Zenana and Purdah. Critics often opine that the novel The Heart Divided is a pre-partition saga centered on two sisters, Zohra and Sughra Jamaluddin, who quarrel over the most popular national debate of colonial India- the merits and demerits of Congress and the Muslim League (Ahmed, 2016, p. 179).

\section{Purdah and Call for Nationalist Cause to the Muslim Women:}

According to Aparna Basu, in India

"the process of nation-building and creation of a national identity was paralelled, in fact, preceded by the growth of social reform movement focusing women's issue" (Basu, 1995, p. 95).

Basu finds anti-colonial movement interlinked with women liberation and social reform in the "Third World" country like India. As the part of the social reform and women liberation during nationalist struggle, leaders involved in this movement called for a struggle against the "veiling system" or the Purdah system. During the nationalist struggle the Muslim world of India too took the Purdah system as the issue of social reform. Muslims especially urban Ashraf Muslims (higher class Muslim) at the loss of power to the Britishers tried to impose the orthodox Islamic values on their private sphere i.e on women in their attempt of saving Islamic civilization. But in the first half of the twentieth century when the nationalist movement was at its peak the issue of women segregation started to be contested in the social/national discourse of educated and elite Muslims. By 1930 s the Purdah debate which was intertwined with Muslim nationalist discourse was running parallel with the Muslim separatist movement. In regard to the emergence of Purdah debate in the Pakistan movement, Willmer evocatively says:

What was clear, however, was that Purdah was now an issue on the social agenda of the Muslim community. Moreover, this emergence of sexual politics into the public arena coincided with the emergence of a separate Muslim nationalism as the dominant political discourse in Muslim India after 1930" (Willmer, 1996, p. 578)

In Momtaz Shah Nawaz's The Heart Divided the reflection of that purdah debate can be seen. The movement for women liberation from Purdah and other segregative social conventions and the rise of female consciousness (that we know as feminism in Western sense) in the country ran parallel with the rise of nationalist movement. Initially, we find Shah Nawaz's heroine Zohra as someone who is always prone to criticizing or discarding all the social conventions born out of the religious orthodoxies: 
That Surraya who goes about like a Farangan Mem and some Hindu Girls. Well, it seems upon being told it would take 20 minutes to get the car going, all three of them jumped out of the car, called a Tonga and drove away in it, God knows where they went. And mind you, Zohra Bibi was without her Burqa. (Shah Nawaz, 2004, p.13)

Here we see that though Zohra criticizes women segregation, she lacks the courage to discard it in her known and familiar world. But the more the national movement was taking a new height the more the issue of women emancipation and the liberation from the customs born out of religious orthodoxies became dominant in socio-political/national discourse. Later, Zohra is able to come out of her home space and her Burqa and is able to become an agent in national movement. In contrast to this Sughra, who in this novel voices the Muslim league's ideologies, tries to preserve the Islamic tradition and to construct her life under Islamic structure. But at the end of the novel she also defies Purdah and other orthodox institutions' when she stands in favour of a moral and Islamically informed state of Pakistan. In the later part of the novel women are seen in the public places wandering freely and Zohra, the protagonist of the novel is seen to participate in an interuniversity debate competition where boys also took part. Breaking the religious orthodoxy and social conventions they make their participation and voice prominent in the national movement. Regarding Muslim women's journey from Purdah to politics and their active participation in the nationalist movement, the character of Habib in the novel points to the changing status of Muslim women:

'Times are changing', said Habib for the second time that day. 'Some Muslim ladies in other parts of India actually took part in the Civil Disobedience Movement last year, and even from our own province, a Muslim lady had gone to the round-table conference. I remember all the English papers praising her speeches last year. (Shah Nawaz, 2004, p.69)

As already mentioned, in the late nineteenth century when the national movement was at its peak, women question in India was newly shaped and it gave birth to the nationalist (also "liberating" as was claimed by the nationalist leaders) concept of "New Women" ${ }^{2}$ or "Modern Indian Women" and also "Mother India". As per Chatterjee's definition, "New Women" apparently discard Purdah, read books, talk politics, join political movements, think and act for the nation's cause. In the initial discussion of this section of the paper, we have found that the female characters are doing exactly the same thing which the New Women are supposed to do. Now the question is: Are Shah Nawaz's female characters prototype of the "New Women" or "Modern Indian Women" whose birth was the result of the initiation of social reform or the women liberation movement at the advent of nationalism. Are women really and finally liberated when they were allowed to participate in the militant nationalism?

To find answers to these questions, we need to bring Chatterjee's analysis in discussion. Chatterjee argues that the modern India had to create a subject position of women in the nationalist discourse to address the British. To serve this purpose, India needed to elaborate and define an "ahistorical and essentialized notion of Indian womanhood" (Chatterjee, 1993, p. 120). He further adds that a marked "difference in the degree and manner of westernization of women, as distinct from men" was essential in this regard (ibid). In this condition India decided to determine the tenets of Indian nationalism by upholding the inner domain of national culture which was founded on the basis of the discovery of 'tradition' on the one hand and modernizing the nation in Western terms on the other. The Indian nationalists ended up dividing the social spaces into two spheres-"spiritual" and "material". The responsibility of the "material" world, the 
outer world (Bahir) falls upon the male so that they can keep pace with the western world in organizing the material lives with their superior technique. On the other hand, to uphold India's distinctive self-identity and uniqueness of its national culture women with traditional and 'ideal' virtue were identified with the "spiritual", the inner domain (Ghar). This "material/spiritual" dichotomy was initiated to challenge the European people on the ground that they had failed to colonize their "inner, essential identity" and their distinctive superior and spiritual culture (Chatterjee, 1993, p. 121). But it didn't reject Westernized modernity rather made it a consistent part of their nationalist project (ibid). This nationalist project gave birth to "new woman" or in Sinha's term the "modern Indian women", who unlike the "selfish" and "shameless" Western women were "modest" and "cultural" enough to be un-self-assertive and unselfish and shy, but educated and "modern" enough to contribute to the larger body politic (Sinha, 2000, p. 626). So, the concept of "New Women" did not give women liberty from the phrase like "Angel in the House", an embodiment of sacrificial and pleasure giving characters, a faithful wife and exemplary mother. It was a transition from one type of bondage of oppression to another kind (Chatterjee, 1993).

Actually as Sinha has commented:

"In the context of rapid westernization of women, modern/westernized women like Sarojini Naidu, could, through service to nation, also appropriate a subject position from which to address the West as Indian" (Sinha, 2000, p.624-625).

The nationalist leaders had to create both subjective and objective position in the nationalist discourse and had to portray women as symbol (symbol of Indian tradition and values) as well as the activist in the national movement to negate the Britisher's "civilizing mission". The construction of the concept of "New Women" or "Modern Indian Women" served the purpose. Now let's take the question: can the concept of "New Women" or "Modern Indian Women" be applied to Muslim Women. "The answer comes in assertive with a rider attached to it" (Ahmed, 2016, p.188). If the concept of "New Women" or "Modern Indian Women" signify those women who discard Purdah or veil, travel in public conveyance, join political movements and even take employments, then the answer is very much affirmative. Having the same opinion, Sonia Nishat Amin considers the late nineteenth and early Twentieth century to be the period in which Muslim women enthusiastically responded to and were awakened into "Modernity". Moreover, the articles by Khairunnesa Khatun, Razia Khatun Chowdhurani, Mahmuda Khatun Siddiqua, published in the magazines like Nabaroor, Saugat, Masik Mohammadi confirm that the role of "New Women" can be ascribed to Muslim women (Ahmed, 2016). But here it must be mentioned that

the emergence of a 'New Women' in the middle class Muslim society (Muslim Bhadramahila as we understand in the nationalist context) was a slower process and it did not happen as widely as among the Hindu Community (Ahmed, 2016, p. 183).

The emergence of Fatima Zinnah, sister of Muhammad Ali Zinnah and the writer Mumtaz Shah Nawaz indicate the rise of the truly "Modern Indian Woman" in the subcontinent. In The Heart Divided Sughra, Najma, Zohra and Zehan-ara are the prototype of Sinha's "truly Modern Indian Women" or "New Woman" (Muslim Bhadramahila) struggling on the path of liberation, emancipation, and empowerment and fighting for freedom of the nation. Women rather "New women" were made the face or prime agent of Ghandhi's ahimsa (non-violence in thought, action and deed), civil disobedience movement and satyagraha. In this novel we find Muslim 
women like Zohra and her friend Suraiya joined the civil disobedience movement and picketing. Moreover, many Muslim women came out of veil and hit the street with the demand of Pakistan, a separate homeland for the Muslims only. Again, even the reflection of Bharatmata or "Mother India", who like the demon slayer Durga or Kali comes out to save her progenies as well as her nation, can be seen in Shah Nawaz's female charactes. In place of sending their sons to the battlefield, they wished to go to the battlefield to save their nation as well as their sons. Sughra said:

Awaken, my sisters in Islam, for until you, who are the mothers of our people, bring your sons to live and die as free men, our nation can't progress (Shah Nawaz, 2004, p.289).

\section{Different Trends of Indian Nationalism and Muslim Women:}

Momtaz Shah Nawaz has successfully presented "the essential ambiguities of nationalism" (Nairn, 1997, p. 71) and "its uneven contour and the silences and omission in the nationalist discourse" (Ahmed, 2016, p. 182) through the debates and narratorial references to the political situation of contemporary India. That time on the one hand mainstream of INC (Indian National Congress) came with secularist nationalist ideology which believed in a unified India. But in opposition to the secularist strand of Indian nationalism Hindu Mahasabha under Bal Gangadhar Tilak's leadership infused religion and culture with politics to propagate Hindu nationalism (Raju, 1993.). Again, the Two Nation theory and Pakistan movement propagated and led by the Muslim League was also another strand of Indian national movement. Shah Nawaz in her novel has provided an account of every strand of the Indian nationalist discourse. She has successfully presented the historiography of the development of the Muslim Separatist Politics and the birth of that Indian politics which led to the fractured independence of the country. On the one hand Mohini, Habib and Zohra dreamt of a multicultural, secular, pluralistic and unified nation and on the other hand Sughra, her husband Mansur and Seikh Jamaluddin stood for Pakistan. In this connection one must

... take note of the novel's effort to represent that Muslim voice, left usually as the footnote to the dominant discourse of separatist politics of pre-independence India, which does not advocate for cleaving of the land and heart but argues for a united struggle against the British for an independent country.(Ahmed 2016, p. 179-180)

Zohra, Habib and Mohini stand for a pluralistic and secular India for which they struggled, debated and joined campaign. Zohra tries to eradicate the inter-racial disharmony by getting his brother married to Mohini, an educated and politically active Hindu girl who fell in love with Habib, brother of Zohra. But not only the society but also law prevented their union. Though British law allowed the inter-racial marriage under certain provisions, Mohini was unable to cross the religio-politic boundaries that prohibited such a union. Zohra's struggle for the unified India is also metaphorically presented through her trail and hardships that she bore for the sake of her brother's marriage to Mohini. Again as already mentioned the novel gives an account of evolution of the Muslim separatist movement and a short introduction to the Hindu nationalism from the perspective of Muslim women. The development of the discourse of Indian nationalism was based upon the dichotomy of "material" and "spiritual" where cultural identity or "national culture" rather Upper Caste Brahmin culture was maintained. Condemning the tendency towards the hegemonisation of the nationalist discourse by branding the majority people's culture as the "national culture" Sughra, comments: 
The Congress Muslims and other nationalist Muslims! A fine way your people have of monopolizing nationalism, as if people belonging to other organizations are not patriotic. As for the so-called nationalist Muslims, it is now obvious that they are the cause of disunity ----the paid traitors. (Shah Nawaz, 2004, p. 309)

In the novel the social turmoil and the process of constructing cultural/social polarizations which India had to undergo before the partition have been demonstrated. It has explicitly accommodated the opinion of those Muslims who felt themselves the "other" in Indian socio-political/national sphere and raised demand of Pakistan. By contrast, through Zohra, Shah Nawaz has presented those Muslims who choose to stay in India as the citizen of India in a multicultural secular set-up. Zohra and Habib's struggle for the unified and multi-religious India echoed the struggle of many Indian Muslims who craved to see themselves as the legitimate citizens of Independent secular India. The novel can to some extent nullify the post-partition political assertion that Muslims are responsible for partition or all Muslims are "proxy Pakistanis". On the one hand she justifies the demand of Pakistan in Muslim community and on the contrary she wants a unified multicultural India. This in-between position or heterogeneous nature of the Muslim community of 1930 and 1940 os has been vividly captured through female perspectives. Thus, Shah Nawaz placed her female characters Sughra and Zohra amidst all the social-political happenings and has successfully been able to give Muslim women's perspective and opinion on every single socio-political situation before the independence. Now the question is whether Shah Nawaz addresses the array of aspects, which Indian Muslim woman as a citizen of a nation or a social being faced. The next section comes up with these issues.

\section{How Much Citizens the Nationalist Muslim Women are?}

Postcolonial feminist asserts that women of a colonized nation had to fight "double colonization"-fight against the colonial power and against the inherent patriarchal structure. While locating Indian Muslim women in the nationalist discourse, one question the scholar of gender and nationalism should ask: If Zohra's dreams of a unified nation and undivided India or Sughra's dream of a new separate nation, Pakistan are fulfilled, would they notice any real changes in their subordinate identities as the Muslim women? Here it must be mentioned that though the Muslim women were able to associate themselves with the nationalist movement, most of them were organized by Muslim League and they hardly achieved any political power in their Pakistan Movement. Then one must wonder about what would actually happen to women after independence? Having an apparently crucial role in the nationalist project, would women really be able to acquire the subject position equal to men in the nation? Having a unified nation or a separate nation, would Muslim women be not entitled to follow up Sharia Law further? Are again Muslim women not forced to return to their traditional home with traditional gender hierarchical rules? If Pakistan is created, would the woman's honor not become the "national honor" as the writings of Muslim nationalist of undivided India during the anti-colonial struggle made a link between national/ cultural identity and womanhood? Would they be veiled or segregated again?

Shah Nawaz in her novel does not shed light on these issues. Rather it might be said that she has finished this novel on an optimistic note. In the later part of the novel, her female characters have been bestowed with the equal agency in the socio-political/national sphere. They are giving lectures, attending meeting held by political parties, going to door to door for collecting votes and asserting their own voices. Even the participations of Muslim women in political domain were satisfactory to Sughra: "That night Sughra told her uncle that she was no 
longer depressed about the political ignorance of Muslim women" (Shah Nawaz, 2004, p.304). Shah Nawaz has shown the success of Muslim women in their struggle against the patriarchal social structure and has given agency to her women who are dreaming of having equal citizenship in their moral state of independent unified India or in Pakistan.

\title{
Conclusion
}

However, at the advent of the national movement, with the constructions of the concepts of "New Women" or "Modern Indian Women", identity of women in India and also the identity of Muslim women were newly shaped. With their new identity, when Muslim women were allowed to join the national movement actively, they felt that they had become liberated now. They felt themselves as liberated and equal as men because suddenly they alongside their male counterpart started to nurture and share the same dream of Pakistan or that of the unified India. Like their men counterpart they started to have the same identity: the patriotic (without the implication of gender bias). Perhaps being perplexed with these sudden changes, women characters of the novel The Heart Divided or Mumtaz Shah Nawaz herself failed to imagine and articulate the silences, omissions and gaps which their new identity had. The novelist perhaps forgot to address whether women would really be able to acquire the subject position equal to men in the nation. But this novel The Heart Divided, written by a Muslim woman can be regarded as the first attempt in the representation of the political/national phenomenon of the colonial India from Muslim women's perspectives.

\section{Endnotes}

\begin{abstract}
"The "race of mothers" or mayer jati are the one whose responsibility is to irradiate her true patriotism to her true santans (patriotic sons). This mayer jati would send his sons or husband for saving the nation and thereby her patriotism can be proved. Sarkar comments: "the first initiative will be seized by flesh-and-blood mothers, there will be a raising of patriotic consciousness, and when this resurgent patriotism of mothers irradiates the son, her task is complete and the burden of regeneration passes on from mother to son" ( Sarkar, 2001, p.258).
\end{abstract}

ii Gandhi's nationalism tried to democratize the whole political sphere and brought women in active nationalist discourse keeping their chastity intact. Women were bestowed with a special role in the charkha movement and in boycotting foreign goods. Thus remaining in home space women were made the agents of nationalism. But during Gandhinian mass movement women were brought into public space for protest and joining the movement. (see Sarkar, 2001.)

iii This particular nationalist rhetoric had different layers: first, the country was evoked in the form of the goddess of the motherland and was worshiped as the mother; secondly, like the naked and angry Kali who destroyed the enemy of her land or the demon slayer Durga women of the nation has to participate to slain the demon colonizers ( see Sinha, 2000. ).

${ }^{\text {iv }}$ Very few Anglophone fictions uphold the representation and position of Muslim women in Nationalist discourse of colonial India. Writers like Begum Rokeya, Attia Hossein, Ismat Chugtai, Iqballunissa Hussein have talked about the form of patriarchy, problems of Muslim household, women-segragation and their struggle to come out Purdah or to be educated. But so far as Indian nationalism and position of Muslim women is concerned, they have not addressed the issue. In this regard mention must be made of Zeenuth Futehally' Zohra or Sara Suleri's Meatless Eyes, narratives that address the issue of Muslim women's participation in and reaction to the nationalist discourse in colonial India.

"The concept of "New Women" emerged in the late Nineteenth century when education for women lastly began. These educated "New Women" could go to school, could have higher education, take employment, join public parties, watch any public entertainment programme and join political movements. But they had to carry feminine 
virtues in their mid set-up, thinking, behavior, dress, religious attitude, social demeanor, eating habits and way of talking etc. the Bhadramohila or the "New women" used to wear Bhrahmika Sari ( a form of wearing sari with blouse, petticoat and shoes) which became the flag-bearer of middle class respected "New Women". (See Chatterjee, 1993)

\section{References}

Ahmed, T. (2016). A Story of Betrayal: Locating Muslim Women in the Nationalist Discourse in Zeenuth Futehally's Zohra, (ed) Living the Postcolonial: Indian Literature in Perspective, 178-194. Kolkata: Gangchil.

Basu, A. (1995). Feminism and Nationalism in India, 1917-1947. Journal of Women's History 7(4), 95107. doi:10.1353/jowh.2010.0459.

Chatterjee, P. (1993). The Nation and its Fragments: Colonial and Postcolonial Histories. New Jeresy: Princeton University Press.

--- (1989). Colonialism, Nationalism, and Colonized Women: The Contest in India. American Ethnologist, 16(4), 622-633. Retrieved August 23, 2020 from http://www.jstor.org/stable/645113

Hai, A. (2013). Adultery behind Purdah and the Politics of Indian Muslim Nationalism in Zeenuth Futehally's "Zohra". Modern Fiction Studies, 59(2), 317-345. Retrieved August 18, 2020, from www.jstor.org/stable/26287650

Nayar, P.K. (2008). Postcolonial Literature: An Introduction. India: Pearson Education

Raju, A. R. (1993). Problematising Nationalism. Economic and Political weekly, 28(27/28), 1433-1438. Retrieved August 18, 2020, from www.jstor.org/stable/4399932

Sarkar, T. (2001). Hindu Wife, Hindu Nation: Community, Religion, and Cultural Nationalism. Delhi: Permanent Black.

Shah Nawaz, M. (2004). The Heart Divided. India: Penguin Books

Sinha, M. (2000). Refashioning Mother India: Feminism and Nationalism in Late-Colonial India. Feminist Studies, 26(3), 623-644. doi:10.2307/3178643

Thapar, S. (1993). Women as Activists; Women as Symbol: A Study of the Indian Nationalist Movement. Feminist Review, (44), 81-96. Doi: 10.2307/1395197

Willmer, D. (1996). Women as Participants in the Pakistan Movement: Modernization and the Promise of a Moral State. Modern Asian Studies, 30(3), 573-590. Retrieved August 18, 2020, from www.jstor.org/stable/312983

Suma Chisti is a PhD research scholar at the Department of Humanities and Social Sciences, IIT Kharagpur. She has been working on Muslim World and Women Question: Evaluating English Novels by Muslim Women Writers of Colonial India. She has completed her M.Phil from the Department of Comparative Literature, Jadavpur University. The title of the dissertation she submitted for her M. Phil was Tradition vs. Modernity: Muslim Women in and out of Purdah. Her areas of interest are Third world feminism, Postcolonial literature, Islamic feminism, Ethnicity and Race and Partition literature. 